\title{
Hubungan Antara Kinerja Dengan Hasil Belajar Siswa Pada Pembelajaran Berbasis Inkuiri Laboraturium Terbatas Di SMA Negeri 13 Samarinda
}

\author{
Nisa Wati ${ }^{*}$, Riskan Qadar ${ }^{2}$, Benyamin Matius ${ }^{3}$ \\ 1,2,3 Program Studi Pendidikan Fisika Fakultas Keguruan dan IImu Pendidikan \\ Universitas Mulawarman, Samarinda-Indonesia \\ *E-mail: nisawz3110@gmail.com
}

\begin{abstract}
Abstrak
Penelitian ini bertujuan untuk mengetahui hubungan antara kinerja dengan hasil belajar siswa pada pembelajaran berbasis Inkuiri Laboraturium Terbatas. Jenis penelitian yang digunakan merupakan penelitian kuantitatif dengan one group pretest-posttest design. Teknik yang digunakan dalam penelitian ini adalah teknik purposive sampling dengan sampel sebanyak 32 orang siswa kelas XI IPA 2 di SMA Negeri 13 Samarinda. Instrumen penelitian yang digunakan merupakan instrumen tes berupa soal essay dan non-tes berupa lembar kerja siswa. Data kinerja diperoleh nilai rata-rata yang terus meningkat dari pertemuan pertama sampai pertemuan keempat. Hasil belajar siswa juga diperoleh nilai rata-rata yang terus meningkat pada pertemuan pertama sampai pertemuan keempat. Berdasarkan analisis korelasi atau analisis hubungan antara kinerja dengan hasil belajar diperoleh nilai $r$ hitung pada setiap pertemuan masing-masing sebesar 0,469, 0,672, 0,558 dan 0,573 . Hasil penelitian menunjukan bahwa terdapat hubungan yang positif antara kinerja dengan hasil belajar berbasis Inkuiri Laboraturium Terbatas.
\end{abstract}

Kata kunci: Pembelajaranan Inkuiri Laboraturium Terbatas, Kinerja, Hasil Belajar

\begin{abstract}
This study aims to determine the relationship between performance and student learning outcomes in learning based on Bounded Inquiry Laboratory. This type of research is a quantitative study with one group pretestposttest design. The technique used in this study was a purposive sampling technique with a sample of 32 students of eleventh grade Natural Science 2 in SMA Negeri 13 Samarinda. The research instrument used was a test instrument in the form of essays and non-test questions in the form of student worksheets. For performance data obtained an average value that continues to increase from the first meeting to the fourth meeting. For student learning outcomes also obtained an average value that continues to increase at the first meeting until the fourth meeting. Based on the analysis of correlation or analysis of the relationship between performance and learning outcomes obtained $r$ count value at each meeting each of $0.469,0.672,0.558$ and 0.573. The results showed that there was a positive relationship between performance and learning outcomes based on the Bounded Inquiry Laboratory.
\end{abstract}

Keywords: Bounded Inquiry Laboratory, Performance, Learning Outcomes

Article History: Received: 17 Januari 2020

Revised : 24 Januari 2020

Accepted: 20 Januari 2020

Published: 31 Januari 2020

How to cite: Wati, N., Qadar, R., \& Matius, B. (2020). Hubungan Antara Kinerja Dengan Hasil Belajar Siswa Pada Pembelajaran Berbasis Inkuiri Laboraturium Terbatas Di SMA Negeri 13 Samarinda, 1(1). pp. 73-80. Retrieved from http://jurnal.fkip.unmul.ac.id/index.php/jpfp/index

Copyright (C) Januari 2020, Jurnal Literasi Pendidikan Fisika

\section{PENDAHULUAN}

Pendidikan merupakan sebuah proses berkelanjutan yang mampu menjadikan siswa secara aktif mengembangkan potensi dirinya untuk memiliki kekuatan spiritual keagamaan, pengendalian diri, kepribadian, kecerdasan, akhlak mulia, serta keterampilan yang 
Hubungan Antara Kinerja...

diperlukan dirinya, masyarakat, bangsa, dan negara yang dilaksanakan secara sadar dan bermakna.

Upaya peningkatan kualitas pendidikan dapat ditempuh melalui peningkatan kualitas pembelajaran dan kualitas sistem penilaiannya. Keduanya saling terkait, sistem pembelajaran yang baik akan menghasilkan kualitas belajar yang baik pula. Kualitas pembelajaran ini dapat dilihat dari hasil penilaiannya. Penilaian pendidikan adalah proses pengumpulan dan pengolahan informasi untuk menentukan pencapaian hasil belajar peserta didik (Lampiran Permendiknas nomor 20, tahun 2007).

Selanjutnya kualitas pembelajaran yang baik akan mendorong pendidik untuk menentukan stretegi mengajar yang baik dan memotivasi siswa untuk belajar yang lebih baik. Rasyid \& Mansyur (dalam Utami, Yudana, dan Marhaeni, 2013) mengemukakan memilih model pembelajaran yang tepat untuk digunakan dalam suatu proses pembelajaran perlu pemikiran dan pertimbangan yang matang bagi seorang guru. Hal-hal yang perlu dipertimbangkan, misalnya kesesuaian dengan muatan materi pembelajaran, waktu, praktis, dapat dilaksanakan, dan memberikan informasi yang sesuai untuk digunakan dalam meningkatkan kualitas belajar.

Fisika merupakan cabang dari ilmu pengetahuan alam (IPA) yang berkaitan dengan cara mencari tahu tentang fenomena alam secara sistematis, sehingga IPA bukan hanya penguasaan kumpulan pengetahuan yang berupa fakta - fakta, konsep - konsep, atau prinsip - prinsip saja tetapi juga merupakan suatu proses penemuan. Namun sering ditemukannya dalam proses pembelajaran fisika belum maksimal karena pemilihan model pembelajaran masih kurang tepat. Banyak siswa kurang aktif dalam proses pembelajaran dan masih jarang sekali melakukan proses penemuan atau praktikum secara mandiri serta proses pembelajaran masih didominasi oleh guru sehingga konsep-konsep dan prinsipprinsip fisika tidak tersampaikan dengan baik. Melihat kondisi tersebut maka perlu adanya inovasi dalam pembelajaran seperti dalam menggunakan pendekatan, strategi, model pembelajaran maupun pada kegiatan penilaian yang membuat kinerja siswa menjadi lebih aktif serta meningkatkan hasil belajar.

Abdurrahman (Jihad \& Haris, 2012) menyatakan hasil belajar adalah kemampuan. Dalam kegiatan pembelajaran atau kegiatan intruksional biasanya guru menetapkan tujuan belajar. Siswa yang berhasil dalam belajar adalah yang berhasil mencapai tujuan-tujuan pembelajaran atau tujuan intruksional. Ketika siswa aktif dalam pembelajaran diharapkan siswa bisa memahami konsep yang berkaitan dengan pembelajaran yang dilaksanakan.

Model pembelajaran inkuiri merupakan rangkaian kegiatan yang menekankan pada proses berpikir secara kritis dan analitis untuk mencari dan menemukan sendiri jawaban dari suatu masalah yang dipertanyakan (Handayama, 2014). Salah satu metode pembelajaran yang dapat dipilih oleh guru untuk meningkatkan partisipasi siswa dalam pembelajaran yaitu model pembelajaran inkuiri terbimbing berbasis inkuiri laboraturium (Maretasari, Subali \& Hartono, 2012).

Model pembelajaran inkuiri laboraturium tersebut memberikan kebebasan bagi siswa mendesain proses pembelajaran yang mereka inginkan, sesuai dengan tujuan yang tertera dalam permasalahan. Sehingga model pembelajaran ikuiri laboraturium cocok diterapkan pada siswa yang memiliki kemandirian belajar yang tinggi (Sanjaya \& Hendra, 2012). Ambarawati \& Suliansya (2018) dalam penelitian model inkuiri laboraturium dapat meningkatkan keterampilan proses sain siswa.

Wenning (2005) membagi jenis pembelajaran inquiry lab menjadi tiga yaitu guided inquiry lab, bounded inquiry lab, dan free inquiry lab. Perbedaan ketiga jenis inquiry lab tersebut terletak pada sumber masalah dan prosedur. Inkuiri Laboraturium terbatas (Bounded Inquiry Laboratory) merupakan tahapan lanjutan dari model pembelajaran level of inquiry dan merupakan tahap kedua dari aktivitas Laboratorium (Inquiry Laboratorium). Peningkatan tahap ini ialah pada kemampuan dan kemandirian peserta didik dalam merancang dan mengadakan eksperimen tanpa banyak panduan, dan untuk kegiatan pre-lab yang jelas (Purwanto, Liliawati \& Hidayat, 2013).

Pada fase ini siswa berusaha untuk mengumpulkan data informasi sebanyak- 
Hubungan Antara Kinerja...

banyaknya, tentang masalah yang mereka hadapi. Data tersebut dapat diperoleh berdasarkan kondisi atau hakikat objek menguji bagaimana proses terjadinya masalah tersebut. Kemudian siswa merumuskan hipotesis (menciptakan hubungan-hubungan dengan sesuatu yang telah diketahui). (Wenning, 2007). Kelebihan indikator inkuiri dari inkuiri lab terbatas adalah mampu melatih peserta didik menyelesaikan permasalahan secara mandiri dengan kegiatan prelab tanpa banyak panduan dari guru melalui kemampuan menyelidiki.

Wenning (2010) membagi Inkuiri menjadi lima tahapan yaitu observasi, manipulasi, generalisasi, verifikasi, dan aplikasi. Pada penelitian Qadar, Syam \& Matius (2016) dalam penelitian "Mengakses Kemampuan Berinkuiri Calon Guru Fisika Melalui Pendekatan Inkuiri Level Demonstrasi Interaktif" Lima tahap tingkatan pembelajaran inkuiri, menunjukkan hasil bahwa calon guru memiliki keterampilan dasar sebagai pengalaman intelektual dalam pembelajaran inkuiri.

Berdasarkan hasil observasi dan wawancara dengan salah satu guru fisika di SMA Negeri 13 Samarinda, bahwa banyak peserta didik yang kurang aktif dan kreatif serta kurang mandiri dalam proses pembelajaran dan mengerjakan tugas serta hasil belajar fisika menunujukkan pencapaian yang tergolong masih kurang. Dalam proses pembelajaran fisika juga masih sering menggunakan pembelajaran konvensional dan sangat jarang melakukan praktikum. Akibat dari masalah tersebut menjadikan kinerja siswa sangat kurang dan mempengaruhi hasil belajar mereka.

Pada penelitian relevan terdahulu (Qadar, 2015) "Pengembangan Asesmen Terintegrasi Pembelajaran Inkuiri pada Perkuliahan Optika Calon Guru Fisika", dari penelitian tersebut diperoleh bahwa analisis kualitatif menunjukkan penggunaan asesmen aspek afektif, kemampuan berinkuiri, formatif, dan sumatif memiliki peran memperbaiki pembelajaran.

Dari observasi tersebut maka model inkuiri laboraturium terbatas sepertinya cocok dipadukan dengan materi suhu dan kalor karena dalam materi tersebut banyak sekali informasi dan materi yang harus diolah oleh siswa sehingga sesusai untuk mengatasi kinerja siswa yang kurang aktif dan untuk melatih kemandirian siswa serta untuk meningkatkan hasil belajar siswa.

Penelitian ini akan diisi dengan materi suhu dan kalor untuk proses pembelajarannya yang dibagi empat pertemuan. Pertemuan pertama diisi dengan materi suhu dan termometer, kedua, pemuaian zat, ketiga azas black dan keempat perpindahan kalor.

Berdasarkan paparan di atas maka rumusan masalah penelitian ini adalah menjelaskan Hubungan Antara Kinerja Dengan Hasil Belajar Berbasis Inkuiri Laboraturium Terbatas Pada Siswa Kelas XI IPA 2 SMA Negeri 13 Samarinda.

Penelitian ini bertujuan untuk mengetahui hubungan atau korelasi antara kinerja dengan hasil belajar siswa setelah dilakukan pembelajaran berbasis inkuiri laboraturium terbatas.

\section{METODE}

Jenis penelitian yang digunakan dalam penelitian ini adalah deskriftif kuantitatif dan metode yang digunakan adalah preeksperimental one gruop pretest-posttest design. Sampel dalam penelitian ini siswa kelas XI IPA 2 SMA Negeri 13 Samarinda tahun ajaran 2018/2019 dengan jumlah 32 orang siswa. Teknik purposive samping adalah teknik yang digunakan untuk pengambilan sampel tersebut.

Untuk data yang dikumpulkan yaitu data tes dan data non tes. Data non tes berupa data kinerja yang diperoleh dari instrumen LKS disertai rubrik penilaian kinerja yang berisi indikator pada setiap tahapan observasi, manipulasi, generalisasi, verifikasi, dan aplikasi nilai tersebut diolah dengan diintrprestasikan kemudian dirata-ratakan. Untuk data tes berupa data hasil belajar yang diperoleh dari instrumen soal tes pilihan ganda pada kegiatan pretest, postest sebanyak 20 butir soal dan soal uraian pada kegiatan tes evaluasi setiap pertemuan materi suhu dan kalor sebanyak 4 butir soal yang kemudian diolah dengan dirata-ratakan kemudian dipersentasekan. Selanjutnya Untuk mencari hubungan antara kinerja dengan hasil belajar berbasis inkuiri laboraturium terbatas data kinerja dan data hasil belajar diolah menggunakan aplikasi SPSS versi 23 for windows. 
Hubungan Antara Kinerja...

\section{HASIL DAN PEMBAHASAN}

HASIL

Penelitian ini dilaksanakan di SMA Negeri 13 Samarinda yang terletak di jalan D. I. Pandjaitan. Penelitian ini dilaksanakan pada semester ganjil tahun pembelajaran 2018/2019. Hasil penelitian dari pembelajaran Fisika pada materi suhu dan kalor digunakan untuk mengetahui hubungan antara kinerja dengan hasil belajar berbasis inkuri laboraturim terbatas (Bounded Inquiry Laboratory). Berdasarkan hasil penelitian yang telah dilakukan, diperoleh data sebagai berikut:

1. Data Kinerja

Diperoleh dari menghitung skor tiap tahapan inkuiri laboraturium terbatas, tiap tahapan memiliki skor nilai maksimal 5 dan kemudian diinterprestasikan.

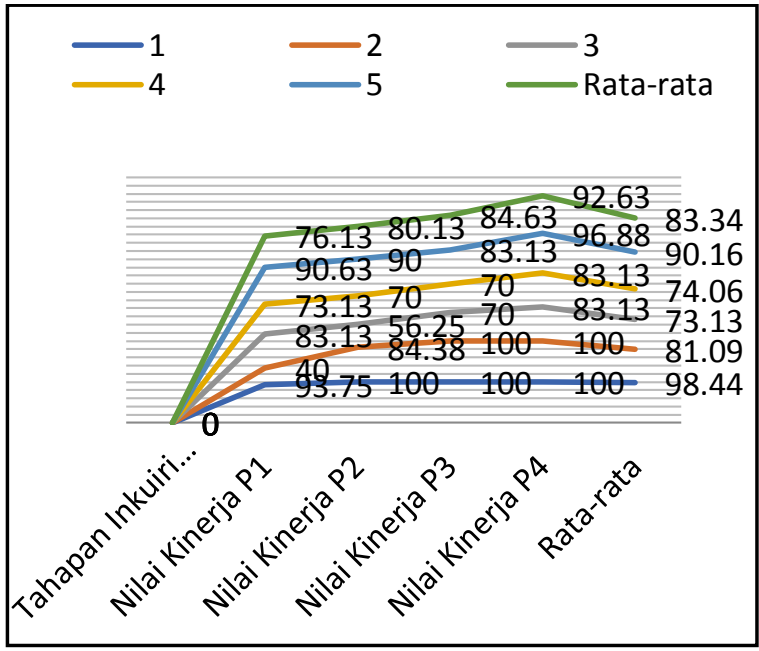

Gambar 1. Data Kinerja

2. Data Hasil Belajar

Diperoleh dari menghitung nilai rata-rata nilai tes siswa tiap pertemuan.

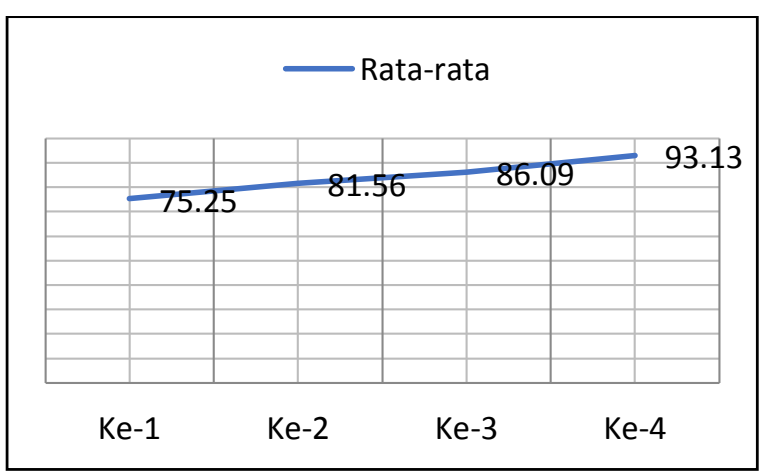

Gambar 2. Nilai Rata-Rata Nilai Tes Evaluasi Siswa
3. Korelasi Kinerja Dengan Hasil Belajar

Setelah diperoleh data kinerja dan data hasil belajar kemudian dikorelasikan sebagai berikut:

Tabel 1. Korelasi Pertemuan 1

\begin{tabular}{|c|c|c|c|}
\hline & & $\begin{array}{c}\text { Kinerja } \\
\text { P1 }\end{array}$ & $\begin{array}{c}\text { Hasil } \\
\text { Belajar P1 }\end{array}$ \\
\hline \multirow{3}{*}{ Kinerja P4 } & $\begin{array}{l}\text { Pearson } \\
\text { Correlation }\end{array}$ & 1 & , 416 \\
\hline & Sig. (2-tailed) & & ,616 \\
\hline & $\mathrm{N}$ & 32 & 32 \\
\hline \multirow{3}{*}{$\begin{array}{l}\text { Hasil } \\
\text { Belajar P4 }\end{array}$} & $\begin{array}{l}\text { Pearson } \\
\text { Correlation }\end{array}$ & ,416* & 1 \\
\hline & Sig. (2-tailed) & ,616 & \\
\hline & $\mathrm{N}$ & 32 & 32 \\
\hline
\end{tabular}

Tabel 2. Korelasi Pertemuan 2

\begin{tabular}{|c|c|c|c|}
\hline & & $\begin{array}{c}\text { Kinerja } \\
\text { P2 }\end{array}$ & $\begin{array}{c}\text { Hasil } \\
\text { Belajar P2 }\end{array}$ \\
\hline \multirow{3}{*}{ Kinerja P2 } & $\begin{array}{l}\text { Pearson } \\
\text { Correlation }\end{array}$ & 1 & ,672 \\
\hline & $\begin{array}{l}\text { Sig. (2- } \\
\text { tailed) }\end{array}$ & & ,735 \\
\hline & $\mathrm{N}$ & 32 & 32 \\
\hline \multirow{3}{*}{$\begin{array}{l}\text { Hasil } \\
\text { Belajar P2 }\end{array}$} & $\begin{array}{l}\text { Pearson } \\
\text { Correlation }\end{array}$ & ,672 & 1 \\
\hline & $\begin{array}{l}\text { Sig. }(2- \\
\text { tailed) }\end{array}$ & ,735 & \\
\hline & $\mathrm{N}$ & 32 & 32 \\
\hline
\end{tabular}

Tabel 3. Korelasi Pertemuan 3

\begin{tabular}{|c|c|c|c|}
\hline & & $\begin{array}{c}\text { Kinerja } \\
\text { P3 }\end{array}$ & $\begin{array}{c}\text { Hasil } \\
\text { Belajar P3 }\end{array}$ \\
\hline \multirow{3}{*}{ Kinerja P3 } & $\begin{array}{l}\text { Pearson } \\
\text { Correlation }\end{array}$ & 1 & ,558 \\
\hline & $\begin{array}{l}\text { Sig. }(2- \\
\text { tailed) }\end{array}$ & & ,633 \\
\hline & $\mathrm{N}$ & 32 & 32 \\
\hline \multirow{3}{*}{$\begin{array}{l}\text { Hasil } \\
\text { Belajar P3 }\end{array}$} & $\begin{array}{l}\text { Pearson } \\
\text { Correlation }\end{array}$ & ,558 & 1 \\
\hline & $\begin{array}{l}\text { Sig. (2- } \\
\text { tailed) }\end{array}$ & ,633 & \\
\hline & $\mathrm{N}$ & 32 & 32 \\
\hline
\end{tabular}

Tabel 4. Korelasi Pertemuan 4

\begin{tabular}{|c|c|c|c|}
\hline & & $\begin{array}{c}\text { Kinerja } \\
\text { P4 }\end{array}$ & $\begin{array}{c}\text { Hasil } \\
\text { Belajar P4 }\end{array}$ \\
\hline \multirow{3}{*}{ Kinerja P4 } & $\begin{array}{l}\text { Pearson } \\
\text { Correlation }\end{array}$ & 1 &, $573^{* \star}$ \\
\hline & $\begin{array}{l}\text { Sig. (2- } \\
\text { tailed) }\end{array}$ & & ,001 \\
\hline & $\mathrm{N}$ & 32 & 32 \\
\hline \multirow{3}{*}{$\begin{array}{l}\text { Hasil } \\
\text { Belajar P4 }\end{array}$} & $\begin{array}{l}\text { Pearson } \\
\text { Correlation }\end{array}$ &, $573^{\star \star}$ & 1 \\
\hline & $\begin{array}{l}\text { Sig. (2- } \\
\text { tailed) }\end{array}$ & ,001 & \\
\hline & $\mathrm{N}$ & 32 & 32 \\
\hline
\end{tabular}

\section{PEMBAHASAN}


Hubungan Antara Kinerja...

Penelitian ini dilakukan sebanyak 6 kali pertemuan pada pertemuan pertama diisi dengan pretest yang digunakan untuk mengetahui pengetahuan awal siswa sebelum diterapkannya pembelajaran inkuiri laboraturium terbatas (Bounded Inquiry Laborartory). Pada pertemuan kedua sampai dengan kelima diisi dengan menerapkan pembelajaran inkuiri laboraturium terbatas. Pertemuan keenam atau pertemuan terakhir diisi dengan posttest untuk mengetahui kemampuan siswa setelah diterapkannya pembelajaran inkuiri laboraturium terbatas (Bounded Inquiry Laborartory).

Pada penelitian ini diterapkan pembelajaran inkuiri laboraturium terbatas yang mana memiliki 5 tahapan yaitu observasi, manipulasi, generalisasi, verifikasi, dan aplikasi (Wenning, 2010). Dari tahapan-tahapan tersebut diperolehlah nilai untuk melihat kinerja siswa pada tiap pertemuan yang bisa dilihat pada gambar berikut.

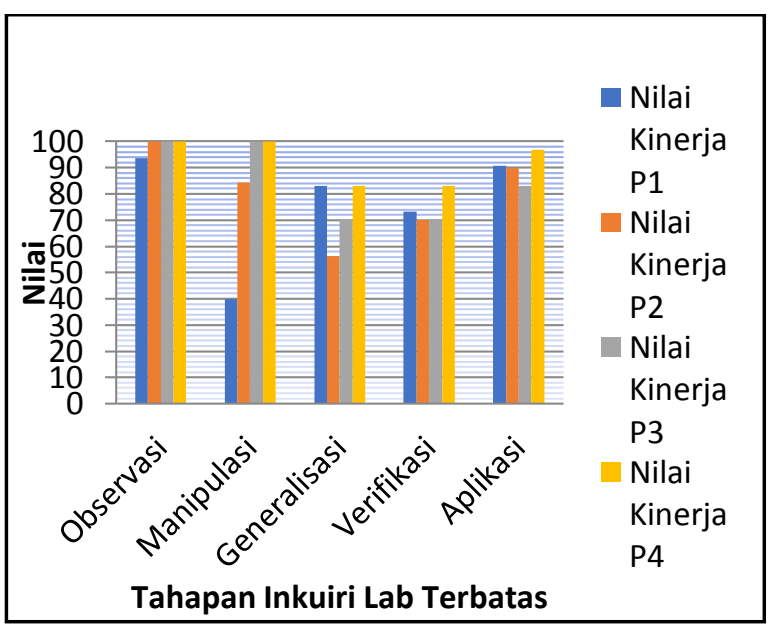

Gambar 3. Grafik Nilai Kinerja

Berdasarkan gambar 3 bisa dilihat bahwa tiap tahapan inkuiri laboraturium terbatas (Bounded Inquiry Laborartory) ada yang meningkat nilai tiap pertemuannya ada juga yang nilainya naik-turun pada tiap pertemuan. Pada tahap observasi yaitu merancang percobaan tiap pertemuannya kinerja meningkat di mana pada pertemuan pertama nilai rata-rata yang diperoleh sebesar 93,75, pertemuan kedua sampai dengan empat diperoleh sebesar 100. Tahap manipulasi yaitu menentukan variabel pertemuan pada tiap pertemuannya juga meningkat terus, pada pertemuan pertama diperoleh nilai rata-rata sebesar 40,00, pertemuan kedua diperoleh sebesar 56,25, pertemuan ketiga diperoleh sebesar 84,38 dan pada pertemuan keempat diperoleh nilai ratarata sebesar 100. Pada tahap generalisasi yaitu membuat kesimpulan dari percobaan, verifikasi yaitu menyimpulkan sesuai teori yang telah dipelajari dan aplikasi yaitu menjawab pertanyaan pada lembar kerja siswa, pada ketiga tahapan tersebut kinerja siswa naik-turun pada tiap pertemuannya. Tahap generalisasi pada pertemuan pertama diperoleh nilai ratarata sebesar 83,13 , pertemuan kedua sebesar 56,25 , pertemuan ketiga sebesar 70,00 , dan pada pertemuan keempat sebesar 83,13. Tahap verifikasi pada pertemuan pertama diperoleh nilai rata-rata sebesar 73,13 , pada pertemuan kedua dan ketiga sebesar 70,00 , dan pada pertemuan keempat sebesar 83,13. Tahap aplikasi pada pertemuan pertama diperoleh nilai rata-rata sebesar 90,63, pada pertemuan kedua sebesar 90,00, pada pertemuan ketiga sebesar 83,13, dan pada pertemuan keempat sebesar 96,88. Namun untuk keseluruhan kinerja siswa bagus dan menjadikan siswa lebih aktif tiap proses pembelajrannya yang sejalan dengan penelitian Sutanto, Suciati \& Nurmiyati (2015) yang mendapatkan hasil bahwa penerapan model pembelajaran BIL dapat meningkatkan keempat aspek KPS peserta didik dan membuat siswa lebih mandiri.

Untuk nilai hasil belajar diperoleh dari perolehan nilai pretest, nilai tes evaluasi tiap pertemuan dan nilai posttest. Nilai yang diperoleh siswa setelah mengerjakan pretest masih di bawah standar nilai KKM yang ditetapkan oleh sekolah yaitu 75 sedangkan nilai rata-rata pretest yang diperoleh siswa yaitu 50,94 yang berarti masuk dalam kategori kurang. Nilai Tes evaluasi dilakukan pada setiap pertemuan pembelajaran berbasis inkuiri laboraturium terbatas (Bounded Inquiry Laboratory) dengan 4 butir soal uraian yang sesuai dengan indikator pembelajaran. Tes evaluasi bertujuan untuk mengetahui seberapa besar pemahaman siswa terhadap materi yang telah diajarkan. Nilai evaluasi dapat dilihat pada gambar berikut. 
Hubungan Antara Kinerja...

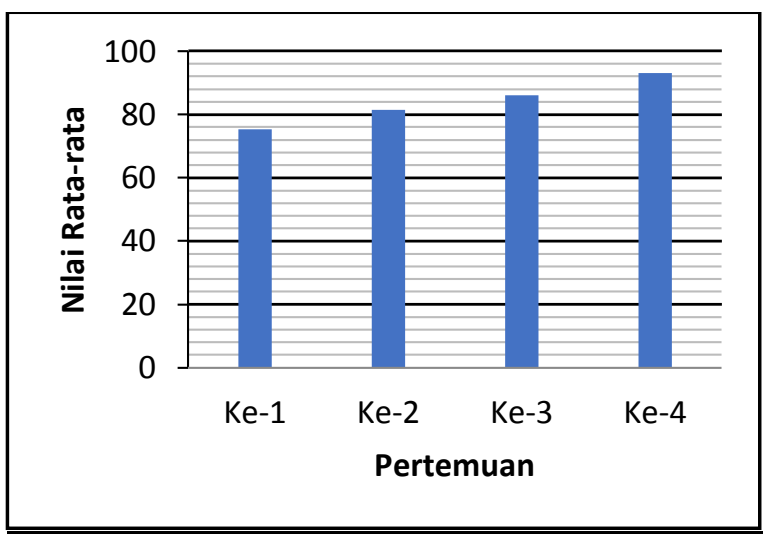

Gambar 4. Nilai Rata-Rata Tes Evaluasi Hasil Belajar

Berdasarkan gambar 4 diketahui nilai ratarata tes evaluasi siswa pada tiap pertemuan proses pembelajaran berbasis inkuiri laboraturium terbatas (Bounded Inquiry Laboratory) cenderung meningkat. Nilai ratarata siswa pada pertemuan pertama dan kedua masuk dalam kategori baik sedangkan pertemuan ketiga dan keempat masuk dalam kategori baik sekali.

Kemudian untuk nilai posttest diperoleh nilai rata-rata siswa adalah sebesar 81,41 yang berarti masuk dalam kategori baik. Berdasarkan dari hasil yang diperoleh siswa setelah diterapkannyan pembelajaran berbasis inkuiri laboraturium terbatas (Bounded Inquiry Laboratory) hasil belajar siswa mengalami peningkatan. Hasil yang dicapai ini sejalan dengan hasil peneltian yang dilaporkan oleh Prani, Parno, \& Hidayat (2018).

Untuk hubungan atau korelasi antara kinerja dengan hasil belajar siswa kelas XI IPA 2 SMA Negeri 13 Samarinda diperoleh pada Tabel 1 menunjukkan hasil analisis korelasi pertemuan bahwa hubungan antara kinerja (variabel $\mathrm{x}$ ) dengan hasil belajar (variabel y) menunjukkan angka korelasi atau nilai $r$ sebesar 0.465 yang berarti hubungan antara keduanya sedang atau cukup diantara kedua variabel tersebut dan tanda positif pada hubungan kedua menujukkan hubungan yang searah, yang dapat diartikan bahwa semakin tinggi hasil kinerja maka semakin tinggi juga hasil belajar, dan sebaliknya jika semakin rendah hasil belajar makan semakin rendah juga hasil percobaan. Namun nilai signifikan pada korelasi adalah sebesar 0.616 yaitu lebih besar dari 0,05 .

Tabel 2 yang menunjukkan hasil analisis korelasi pada pertemuan kedua bahwa hubungan antara kinerja (variabel $\mathrm{x}$ ) dengan hasil belajar (variabel y) menunjukkan angka korelasi atau nilai $r$ sebesar 0.672 yang berarti hubungan antara kedua variabel kuat, ini dikarenakan siswa mulai beradaptasi pada proses pembelajaran namu pada pertemuan kedua ini nilai signifikan 0,672 lebih besar dari 0,05 yang berarti kurang signifikan.

Pada Tabel 3 adalah tabel koreralasi untuk peretemuan ketiga yang diketahui $r$ hitungnya adalah sebesar 0.558 menunjukkan hubungan antara keduanya sedang atau cukup, tanda positif pada hubungan kedua menujukkan hubungan yang searah, yang dapat diartikan bahwa semakin tinggi hasil kinerja maka semakin tinggi juga hasil belajar, dan sebaliknya jika semakin rendah hasil kinerja maka semakin rendah juga hasil belajar. Nilai signifikan 0,633 yang berarti terdapat korelasi yang tidak signifikan.

Berdasarkan Tabel 4 diatas menunjukkan hasil analisis korelasi pertemuan keempat bahwa hubungan antara kinerja (variabel $\mathrm{x}$ ) dengan hasil belajar (variabel y) menunjukkan angka korelasi atau nilai $r$ sebesar 0.573 menunjukkan hubungan antara keduanya sedang atau cukup, tanda positif pada hubungan kedua menujukkan hubungan yang searah, yang dapat diartikan bahwa semakin tinggi hasil kinerja maka semakin tinggi juga hasil belajar, dan sebaliknya jika semakin rendah hasil kinerja maka semakin rendah juga hasil belajar. Pada pertemuan keempat ini nilai signifikan 0.001 lebih kecil dari 0,05 yang berarti menunjukkan korelasi yang signifikan diantara korelasi tersebut.

Walaupun dari semua analasis korelasi ada memiliki perbedaan tingkat hubungan dan nilai signifikan tetapi semua hasil analisis korelasi memiliki hubungan yang positif dan searah dimana bahwa semakin tinggi hasil kinerja maka semakin tinggi juga hasil belajar, dan sebaliknya jika semakin rendah hasil kinerja maka semakin rendah juga hasil belajar, sejalan dengan Maretasari, Subali \& Hartono (2012) bahwa inkuiri laboraturium mempunyai pengaruh positif yang signifikan terhadap hasil belajar dan sikap ilmiah siswa serta didapati suatu hubungan, yaitu setiap terjadi peningkatan sikap ilmiah akan berpengaruh terhadap hasil belajar siswa. 
Hubungan Antara Kinerja...

\section{PENUTUP}

Berdasarkan hasil penelitian dan analisis data yang telah dilakukan mengenai hubungan antara kinerja dengan hasil belajar berbasis inkuri laboraturium terbatas (Bounded Inquiry Laboratory) pada siswa kelas XI IPA 2 SMA Negeri 13 Samarinda, maka dapat disimpulkan bahwa terdapat peningkatan hasil kinerja dan terdapat adanya hubungan yang positif dan menujukkan hubungan yang searah, yang diartikan bahwa semakin tinggi hasil kinerja maka semakin tinggi juga hasil belajar, dan sebaliknya jika semakin rendah hasil belajar makan semakin rendah juga hasil kinerja.

Adapun saran yang dapat penulis berikan adalah sebagai berikut: 1) bagi peserta didik agar terus belajar dan aktif serta meningkatkan hasil belajarnya, sehingga mempunyai kemampuan yang tinggi dan baik dalam mengatasi permasalahan dalam pembelajaran; 2) bagi guru, dapat menerapkan atau memperkenalkan siswa model pembelajaran yang baru dan inovatif sehingga siswa dapat mengembangkan kemampuan mereka untuk mengatasi permasalahan atau persoalan dalam belajar; 3) bagi sekolah, agar dapat meningkatkan fasilitas yang sudah ada agar proses belajar mengajar dikelas bisa lebih baik lagi; dan 4) bagi peneliti selanjutnya, diharapkan agar bisa menggali informasi lebih lanjut mengenai model Inkuiri Laboraturium Terbatas (Bounded Inquiry Laboratory) dan peneliti hendaknya juga bisa mengurangi berbagai macam faktor yang dapat menghambat ketercapaian proses pembelajaran.

\section{DAFTAR PUSTAKA}

Ambarawati, E., \& Suliyanah. (2018). Penerapan Model Inquiry Laboratory Untuk Melatihkan Keterampilan Proses Sains Peserta Didik. Jurnal Inovasi Pendidikan Fisika, 7(3), 367-368.

Handayama, J. (2014). Model dan Metodelogi Penelitian Kreatif dan Berkarakter. Bogor: Ghalia Indonesia.

Jihad, A., \& Haris, A. (2012). Evaluasi Pembelajaran. Yogyakarta: Multi Pressindo.
Maretasari, E., Subali, B., \& Hartono. (2012). Penerapan Model Pembelajaran Inkuiri Terbimbing Berbasis Laboraturium Untuk Meningkatkan Hasil Belajar dan Sikap IImiah Siswa. Unnes Physics Education Journal, 1(1), 27-31

Prani, A.I.E., Parno, dan Hidayat, A. (2018). Keterampilan Berpikir Kritis Pada Bounded Inquiry Lab: Analisis Kuantitatif dan Kualitatif. Momentum: Physics Education Journal, 2(1), 29-36.

Purwanto, Liliawati, W., \& Hidayat, R. (2013). Analisis Kemampuan Inkuiri dan Hasil Belajar Siswa Sekolah Menengah Pertama Melalui Model Hierarki Of Inquiry. Prosiding pertemuan ilmiah XXVI HFI Jateng \& DIY.

Qadar, R. (2015). Pengembangan Asesmen Terintegrasi Pembelajaran Inkuiri Pada Perkuliahan Optika Calon Guru Fisika. Bandung: Universitas Pendidikan Indonesia.

Qadar, R., Syam, M., \& Matius, B. (2016). Mengakses Kemampuan Berinkuiri Calon Guru Fisika Melalui Pendekatan Inkuiri Level Demonstrasi Interaktif. Jurnal Riset Pendidikan Fisika, 1(1), 33-39

Sanjaya \& Hendra, I.P. (2012). Pengaruh Model Pembelajaran Inkuiri Laboraturium Terhadap Keterampilan Berpikir Kreatif dan Keterampilan Proses Sains Siswa Ditinjau dari Kemandirian Siswa. Jurnal IImu Pendidikan Fisika, 2(1), 9-13.

Sutanto, V. A., Sucianti dan Nurmiyanti. (2015). Penerapan Bounded Inquiry Laboratory Untuk Meningkatkan Keterampilan Proses Sains Peserta Didik Kelas XI Mia 2 SMA N 1 Sukoharjo. Jurnal Bio-Pendagogi, 4(2), 5-9.

Utami, B.L., Yudana, M.I., dan Marhaeni, A.A. I.N. (2013). Pengaruh Implementasi Asesmen Portofolio Terhadap Kemampuan Menulis Dalam Bahasa Inggris Ditinjau Darimotivasi Berprestasi Siswa Kelas XI Man Amlapura. E-Journal Program Pascasarjana Universitas Pendidikan Ganesha Program Studi Administrasi Pendidikan, 4(1), 1-12. 
Wenning, C. J. (2005b). Implementing InquiryBased Intruction in The Science The Improvment-of-Practice Problem. Journal of Physics Teacher Education Online, 2(4), 9-15.

Wenning, C.J. (2005a). Levels of inquiry: Levels of inquiry: Hierarchies of pedagogical practices and inquiry processes. Journal of Physics Teacher Education Online, 2(3), 3-12.

Wenning, C.J. (2007). Assessing inquiry skills as a component of scientific literacy. Journal of Physics Teacher Education Online, 5(4), 10-16

Wenning, C.J. (2010). Levels of inquiry: Using inquiry spectrum learning sequences to teach science. Journal of Physics Teacher Education Online, 4(2), 11-19 